\title{
Navy Ability Development Strategy using SWOT Analysis-Interpretative Structural Modeling (ISM)
}

April Kukuh Susilo

Directorate of Postgraduate, Indonesian Naval Technology College, Krembangan, Surabaya 60187, Indonesia. Udisubakti Ciptomulyono

Institute of Sepuluh November, Surabaya, Keputih, Sukolilo, Surabaya 6011, Indonesia.

I Nengah Putra

Directorate of Postgraduate, Indonesian Naval Technology College, Krembangan, Surabaya 60187, Indonesia.

Ahmadi

Directorate of Postgraduate, Indonesian Naval Technology College, Krembangan, Surabaya 60187, Indonesia.

Okol Sri Suharyo

Directorate of Postgraduate, Indonesian Naval Technology College, Krembangan, Surabaya 60187, Indonesia.

\begin{abstract}
Indonesia as an archipelagic country has potential problems that pose a threat. This can be inferred because of the security lack and the sovereignty in the sea border area. The aim of the paper is to formulate a development strategy of posture capabilities of the Indonesian Navy to encounter security threats in the national territorial waters. In this research using the integration of SWOT analysis method and Interpretative Structural Modeling (ISM) in formulating strategies of Indonesian Navy posture capability development. The result of this paper Based on SWOT analysis, the total strategy that has been formulated is 10 (ten) sub strategies which determine the development of the Navy posture abilities. Based on ISM Method, it is evident that Increase of state budget percentage for the maritime sector in the development of Navy capability and other stakeholders as (ST)1 is a significant driver for the development of the strategy. Utilization of the abundant labor force in recruitment of Navy Personnel as (SO)2 is at level II; Build a strong foundation and infrastructure of information systems in the maritime territory to cope the cyber threats as (ST)3 and Cooperation with developed countries with technology transfer for military infrastructure development as (WT)2 are at level III; Negotiations with neighboring countries in trans-state sea border agreements as (ST)2 is at level IV; Establish an integrated task force with fellow stakeholders in maritime security as (WO) 1 and Establish a task force to eradicate corruption and illegal levies on marine sector as (WO)2 are at level V; Utilization of marine resources to support renewable energy at sea, and open employment for the community as (SO) 1 is at level VI. Equitable development of maritime infrastructure and connectivity in coastal and border areas as (WT)1 and The use of the country's active-free politics as a mediator for China and US hegemony in Asia Pacific as (SO) 3 are at the top of the hierarchy models of structural modeling based on interpretation. The key strategy is an increase of state budget percentage for the maritime sector in the development of Navy ability.
\end{abstract}

\section{Keywords}

Posture of Indonesian Navy, SWOT Analysis, Interpretative Structural Modeling (ISM)

\section{Introduction}

Indonesia as an archipelagic country has potential problems that become a threat in the national territorial waters (Putra, Hakim, Pramono, \&
Leksono, 2017). The threats include violations of law covering armed robberies, human smuggling (illegal immigrants), smuggling of goods, illegal fishing, marine pollution, illegal exploration and 
exploitation of natural resources, as well as other violations in water areas (Poerwowidagdo, 2015). On the other side, the Indonesian Navy (TNI AL ) is a main component to protect maritime security (Susilo, Ahmadi, Suharyo, \& Pratisna, 2017). The TNI AL posture is structured on the basis of several components in the integrated fleet weapon system, consists of: Warship, Airplanes, Naval Base and Marine Corps (Yogi, Rizal, Ahmadi, \& Suharyo, 2017).

The aim of paper is to formulate a posture of Indonesian navy development strategy to encounter the threat of national maritime security. This paper uses integrating SWOT analysis and Interpretative Structural Modeling (ISM) to formulate the development strategy. SWOT analysis uses to identify and formulate some strategy of Navy posture capability. ISM method uses to identify and map relationships between strategies.

To support the research, this paper has many literatures. SWOT analysis uses to applying the priority model of engineering faculty development strategy (Živković, Nikolić, Djordjević, Mihajlović, \& Savić, 2015). SWOT analysis to formulate the development strategy of traditional shipyard industry (Lumaksono, 2014). SWOT analysis to provide an appropriate strategic analysis to plan the relocation of the naval base (Yogi, Rizal, Ahmadi, \& Suharyo, 2017). SWOT to prioritization of strategy for viticulture development (Dibokić, Nikolić, Djordjević, Panić, \& Živković, 2017).

The literatures about Interpretative Structural Modeling (ISM). ISM for analyzing interactions between barriers to just-in-time (JIT) production operations (Jadhav, Mantha, \& Rane, 2015). ISM to analysis of core industry competencies in Pekalongan City (Paramitha \& Nurcahyo, 2018). ISM uses for identification of readiness in implementing business Intelligence project (Farrokhi, Pokorádi, \& Bouini, 2018). ISM uses to identify the drivers of travel / tourism growth and build relationships between enablers (Roy \& Misra, 2016). ISM uses to study various aspects and correlations between youth and sustainable rural development (Panackal \& Singh, 2015).

This research is expected to contribute to the science of military operations research in the concept of strength development and ability.

This paper is organized as follows. Section 2 explains the basic concept the model of strategy development. Section 3 gives result of paper. Section 4 describes the analysis of development strategy for Indonesian Navy (TNI AL) posture. Section 5 presents the conclusion of paper.

\section{Navy Ability (Posture of Navy)}

The development of posture is projected towards a regional maritime with an active principle that is defensive. This posture is designed to address possible threats, actual problems, and to support defense forces. There are many components in the posture, such as (Ministry of Defence, 2015):

1. Strength.

The main components of strength based on Integrated Fleet Weapon System consist of Warship, Airplanes, Naval Base and Marine Corps.

2. Capability.

The capabilities of the Navy are designed for intelligence, diplomacy, defense, security, regional empowerment and support capabilities.

3. Deployment.

The deployment of the Navy includes organization, strength and ability.

This is aligned with the establishment of a fleet command organizational structure, including centralized, territorial and support unit strength.

\section{Material/Method}

\subsection{SWOT Analysis}

SWOT analysis is an effective strategic planning tool for analyzing the organization of internal and external influences (Gürel \& Tat, 2017). SWOT analysis consists of internal and external factors. Internal factors (strengths, weaknesses) are used to test assets within an organization (Marić \& Ilić, 2012). External factors are used (opportunities, threats) to investigate factors in the environment beyond the organizational control that affect organizational performance (Gürel \& Tat, 2017), (Njoroge, Ongeti, Kinuu, \& Kasomi, 2016). Information obtained can be integrated in different matrix combinations of the four factors in determining strategies for long-term progress (Yuksel \& Dagdeviren, 2007; Živković, Nikolić, Djordjević, Mihajlović, \& Savić, 2015).

The SWOT analysis shows the right strategy in four categories (SO, ST, WO and WT) (Dibokić, Nikolić, Djordjević, Panić, \& Živković, 2017). Strength-Opportunity (SO), this strategy takes advantage of opportunities by using existing strengths. Strength-Threat (ST), this strategy uses the strength to eliminate or reduce the effects of 
threats (Marić \& Ilić, 2012). WeaknessOpportunity (WO) strategies are used to take benefit from opportunities by external environmental factors with fixing the weaknesses. Last, Weakness-Threat (WT) strategies are used to reduce an impact from threat with fixing the (Dibokić et al., 2017).

Table 1 Matrix of SWOT

\begin{tabular}{c|c|c}
\hline $\begin{array}{c}\text { INTERNAL/EXTERNAL } \\
\text { FACTOR }\end{array}$ & $\begin{array}{c}\text { STRENGTH } \\
\text { (S) } \\
\text { (Maximal) }\end{array}$ & $\begin{array}{c}\text { WEAKNESS } \\
\text { (W) } \\
\text { (Minimal) }\end{array}$ \\
\hline $\begin{array}{c}\text { OPPORTUNITIES (O) } \\
\text { (Maximal) }\end{array}$ & S-O strategy & W-O Strategy \\
\hline $\begin{array}{c}\text { THREATS (T) } \\
\text { (Minimal) }\end{array}$ & S-T Strategy & W-T Strategy \\
\hline
\end{tabular}

Source: Malik, Al-Khatani, \& Naushad, 2013.

\subsection{Interpretative Structural Modeling (ISM)}

The interpretative structural modeling (ISM) used for ideal planning, is an effective method because all elements can be processed in a simple matrix (Wang, 2015). ISM was first proposed by Warfield in 1973. The interpretative structural modeling is a methodology that aims to identify the relationship between a particular item, which defines a related problem or issue (Attri, Dev, \& Sharma, 2013) and a suitable modeling technique for analyzing the influence of one variable on another variable (Solke \& Singh, 2018).

ISM has been well proven to identify structural relationships among system-specific variables. The basic idea is to use practical experience and expert knowledge to parse complex systems into multiple sub-systems and build structured structural models (Firoz \& Rajesh, 2012). The ISM-based approach is one of the versatile and powerful techniques that have been used to solve complex multi-factor problems. ISM is interpretative, since the group assessment selected for the study determines whether and how the related variables (Balaji, Velmurugan, Prapa, \& Mythily, 2016). There are procedures or stages in the use of the ISM method, such stages as :

1. Identify elements of a system. The system elements and sub-elements of the system are identified. This step can be done through research, brainstorming or other.

2. Development of Structural Self Interaction Matrix (SSIM).

The development of an interpretive structural model begins with the preparation of a structural self-interaction matrix, indicating the direction of the contextual relationship between elements.

Table 2 Rule of SSIM Development.

\begin{tabular}{c|l}
\hline Symbol & $\begin{array}{l}\text { Relationship between row (i) and Column } \\
\text { (j) elements }\end{array}$ \\
\hline $\mathrm{V}$ & $\begin{array}{l}\text { Barrier j will lead to barrier i, not in reserve } \\
\text { direction }\end{array}$ \\
\hline $\mathrm{A}$ & $\begin{array}{l}\text { Barrier i will lead to barrier j, not in reserve } \\
\text { direction }\end{array}$ \\
\hline $\mathrm{X}$ & $\begin{array}{l}\text { Barrier I and j will lead to each other, in both } \\
\text { directions }\end{array}$ \\
\hline $\mathrm{O}$ & Barrier i and j are unrelated \\
\hline
\end{tabular}

Source: Malik et al., 2013.

3. Reachability Matrix.

From the self-interaction matrix (SSIM), the relational indicator is converted to binary numbers 0 and 1 to obtain a square matrix, called the reachability matrix (Hussain, 2011).

Table 3 Sample of Reachability Matrix.

\begin{tabular}{c|c|c|c|c|c|c}
\hline No & Code & Strategies & $\mathbf{4}$ & $\mathbf{3}$ & $\mathbf{2}$ & $\mathbf{1}$ \\
\hline 1 & & & A & O & O & - \\
\hline 2 & & & V & A & - & \\
\hline 3 & & & V & - & & \\
\hline 4 & & & - & & & \\
\hline \multicolumn{6}{c}{ Source: Hussain, 2011. }
\end{tabular}

4. Partition level.

The elements are classified into different levels of the ISM structure that will be formed. For this purpose, two devices are associated with each element in the system, namely reachability set (Ri) which is a set of elements that can be achieved by the element $\mathrm{Ei}$, and antecedent set (Ai) which is a set of elements where the Ei element can be achieved.

5. The construction of interpretative structural modeling (ISM).

6. MICMAC analysis.

MICMAC is used to check driving power and dependence power. Variables have been grouped into four criteria known as Autonomous, Linkage, Dependent and Driving / independent. The following is the meaning of the four categories (Panackal \& Singh, 2016): a) Variable Autonomous. b) Linkage Variables. c) Dependent Variables. d) Independent Variables. 


\section{Conceptual Framework}

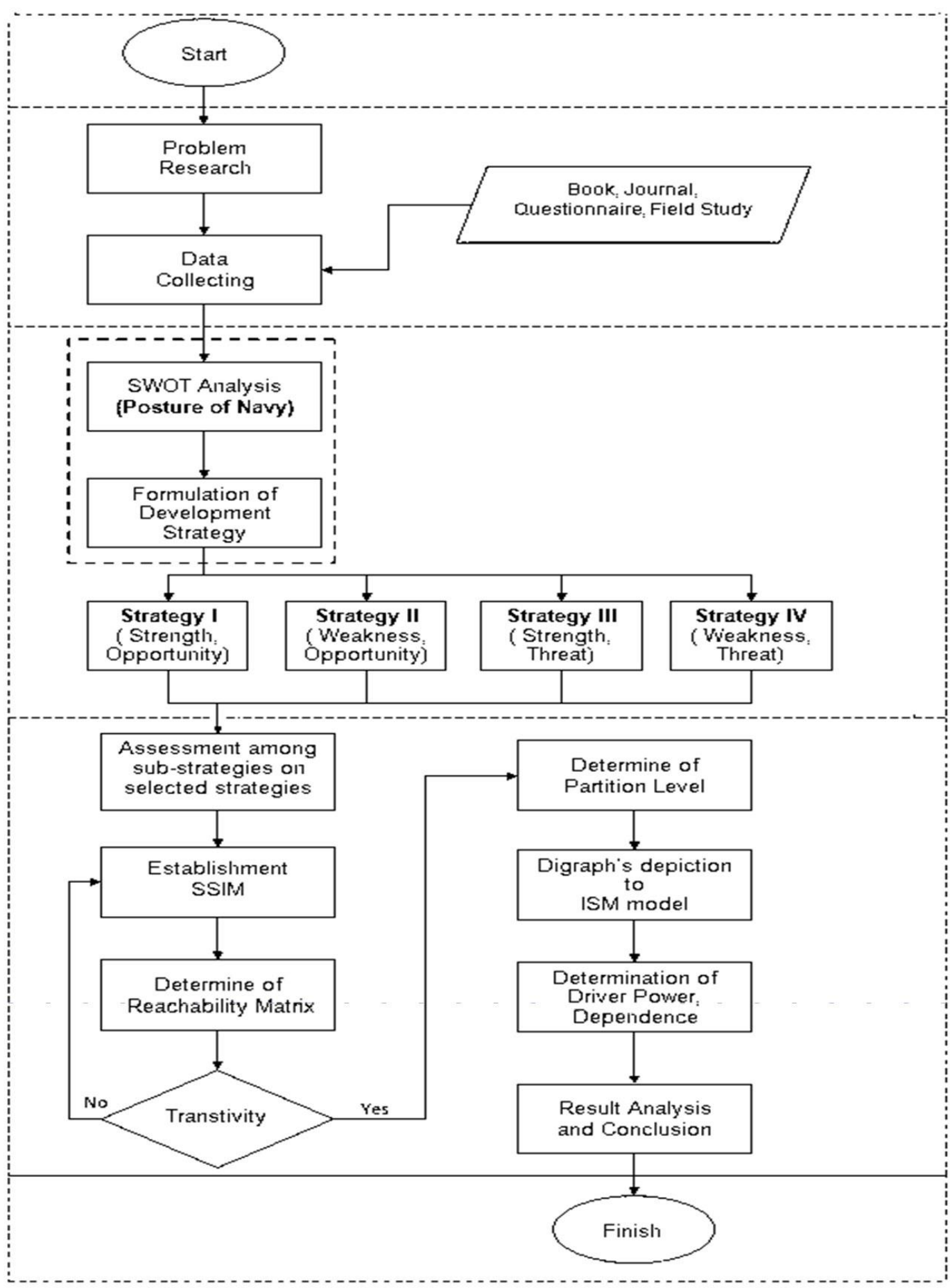

Figure 1 Conceptual Framework of Research.

Source: Author

\section{Result}

\subsection{Strategy Formulation}

The analysis of Navy ability development strategies using SWOT (Strength, Weakness, Opportunities and Threats) is maximizing Strength and Opportunities, while minimizing
Weakness and Threats. The data taken from interviews and observations with six experts. The results of the SWOT analysis are described as follows: 
Table 4 Result Of Internal And External Factor Identified.

\begin{tabular}{|c|c|}
\hline \multicolumn{2}{|c|}{ Internal Factors } \\
\hline Strength (S) & Weakness (W) \\
\hline $\begin{array}{l}\text { S1. Geographical position of Indonesia between two } \\
\text { oceans and continents. } \\
\text { S2. The number of main weapon system that many. } \\
\text { S3. Character and history as a maritime nation. } \\
\text { S4. The defense budget that continues to increase. } \\
\text { S5. Demographic bonus of the population with a large } \\
\text { workforce. } \\
\text { S6. Maritime-oriented from the Government Policy. } \\
\text { S7. Naval Diplomacy is good. } \\
\text { S8. A Militant soldier. }\end{array}$ & $\begin{array}{l}\text { W1. Maritime security policy that still overlap with other } \\
\text { w2. Age of vulnerable weapon system and technology that } \\
\text { still lag. } \\
\text { W3. Maritime domain awareness is minimized. } \\
\text { W4. Defense budget mostly for soldier's salary. } \\
\text { W5. Information systems are still vulnerable to attacks from } \\
\text { W6. Inadequate naval base infrastructure. } \\
\text { W7. Welfare for the Personnels of the Navy is limited. }\end{array}$ \\
\hline \multicolumn{2}{|c|}{$\begin{array}{l}\text { External Factors } \\
\end{array}$} \\
\hline Opportunity (0) & Threat (T) \\
\hline $\begin{array}{l}\text { O1. Indonesia has the opportunity to become the second } \\
\text { largest maritime country in the world. } \\
\text { O2. As a new hegemony in Asia-pacific, a counterweight of } \\
\text { China and US influence. } \\
\text { O3. The high economic growth encourages the growth of } \\
\text { goods traffic by sea. } \\
\text { O4. A good national state budget encourages increased } \\
\text { strength for the Navy ability. } \\
\text { O5. Demographic bonus as a large market and abundant } \\
\text { labor for the Navy. } \\
\text { O6. The existence of technology transfer for maritime } \\
\text { service industry. } \\
\text { O7. Participate in the determination of world maritime } \\
\text { security policy as a member of IMO. }\end{array}$ & $\begin{array}{l}\text { T1. Piracy. } \\
\text { T2. Illegal immigrants and human trafficking. } \\
\text { T3. Drug trafficking, smuggling of goods, weapons and } \\
\text { military technology. } \\
\text { T4. The threat of terrorism both from inside and outside the } \\
\text { country. } \\
\text { T5. Armed attacks, and violations of territorial boundaries } \\
\text { from other countries. } \\
\text { T6. The threat of cyber attack; espionage; sabotage. } \\
\text { T7. Hunting and looting of marine resources, and illegal } \\
\text { fishing. } \\
\text { T8. Communal conflict. } \\
\text { T9. Threats from loss of natural resources and outer } \\
\text { islands. }\end{array}$ \\
\hline
\end{tabular}

Source: Data Analytic from Author

Based on the results of respondents' judgement, there are several internal factors that become strengths and weaknesses as contained in the table upon. It has eight points for strength analysis factor and seven points for weakness analysis factor. It has seven points for opportunity analysis factor and nine points for threat analysis factor.

Table 5 Result of Strategy.

\begin{tabular}{|c|c|}
\hline \multicolumn{2}{|c|}{ Strategies } \\
\hline Strength-Opportunity (S-O) & Weakness-Opportunity (W-O) \\
\hline $\begin{array}{l}\text { (SO)1. Utilization of marine resources to support } \\
\text { renewable energy at sea, and open employment for } \\
\text { the community. } \\
\text { (SO)2. Utilization of the abundant labor force in recruitment } \\
\text { of Navy Personnel. } \\
\text { (SO)3. The use of the country's active-free politics as a } \\
\text { mediator for China and US hegemony in Asia } \\
\text { Pacific. }\end{array}$ & $\begin{array}{l}\text { (WO)1. Establish an integrated task force with fellow } \\
\text { stakeholders in maritime security. } \\
\text { (WO)2. Establish a task force to eradicate corruption and } \\
\text { illegal levies on marine sector. }\end{array}$ \\
\hline \multicolumn{2}{|r|}{ Weakness-Threat (W-T) } \\
\hline $\begin{array}{l}\text { (ST)1. Increase of state budget percentage for the } \\
\text { maritime sector in the development of Navy } \\
\text { capability and other stakeholders. } \\
\text { (ST)2. Negotiations with neighboring countries in trans- } \\
\text { state sea border agreements. } \\
\text { (ST)3. Build a strong foundation and infrastructure of } \\
\text { information systems in the maritime territory to cope } \\
\text { the cyber threats. }\end{array}$ & $\begin{array}{l}\text { (WT)1. Equitable development of maritime infrastructure } \\
\text { and connectivity in coastal and border areas. } \\
\text { (WT)2. Cooperation with developed countries with } \\
\text { technology transfer for military infrastructure } \\
\text { development. }\end{array}$ \\
\hline
\end{tabular}

Source: Data Analytic from Author

The formulated strategy consists of 4 categories namely Strategy I (StrengthOpportunity), Strategy II (WeaknessOpportunity), Strategy III (Strength-Threat),
Strategy IV (Weakness-Threat). Strategy I consists of 3 strategies. Strategy II consists of 2 strategies. Strategy III consists of 3 strategies. Strategy IV consists of 2 strategies. 
Table 6 Strategy Collected.

\begin{tabular}{l|c}
\hline \multicolumn{1}{c|}{ Strategies } & Symbol \\
\hline $\begin{array}{l}\text { Utilization of marine resources to support renewable energy at sea, and open employment for the } \\
\text { community }\end{array}$ & (SO)1 \\
\hline Utilization of the abundant labor force in recruitment of Navy Personnel & (SO)2 \\
\hline The use of the country's active-free politics as a mediator for China and US hegemony in Asia Pacific. & (SO)3 \\
\hline $\begin{array}{l}\text { Increase of state budget percentage for the maritime sector in the development of Navy capability } \\
\text { and other stakeholders }\end{array}$ & (ST)1 \\
\hline Negotiations with neighboring countries in trans-state sea border agreements. & (ST)2 \\
\hline $\begin{array}{l}\text { Build a strong foundation and infrastructure of information systems in the maritime territory to cope } \\
\text { the cyber threats. }\end{array}$ & (ST)3 \\
\hline Establish an integrated task force with fellow stakeholders in maritime security. & (WO)1 \\
\hline Establish a task force to eradicate corruption and illegal levies on marine sector. & (WO)2 \\
\hline Equitable development of maritime infrastructure and connectivity in coastal and border areas. & (WT)1 \\
\hline Cooperation with developed countries with technology transfer for military infrastructure development. & (WT)2 \\
\hline
\end{tabular}

Source: Data Analytic from Author

Based on SWOT analysis, the total strategy that has been formulated is 10 (ten) sub strategies which determine the development of the Navy posture abilities. At a later stage the strategies will be modeled in the ISM method (table 6). The first step in ISM processing is to create Structural Self Interaction Matrix (SSIM), where the variables make their contextual relationship by making one variable $\mathrm{i}$ and variable $\mathrm{j}$.

\subsection{Interpretative Structural Modeling (ISM) Method}

Table 7 Structural Self Interaction Matrix (SSIM).

\begin{tabular}{|c|c|c|c|c|c|c|c|c|c|c|c|c|}
\hline No & Code & Strategies & 10 & 9 & 8 & 7 & 6 & 5 & 4 & 3 & 2 & 1 \\
\hline 1 & (SO)1 & $\begin{array}{l}\text { Utilization of marine resources to support renewable energy } \\
\text { at sea, and open employment for the community }\end{array}$ & $\mathrm{O}$ & $A$ & V & V & $\mathrm{O}$ & V & A & 0 & $\mathrm{O}$ & - \\
\hline 2 & (SO)2 & $\begin{array}{l}\text { Utilization of the abundant labor force in recruitment of Navy } \\
\text { Personnel }\end{array}$ & $\mathrm{O}$ & $\mathrm{O}$ & $A$ & A & $A$ & $\mathrm{O}$ & V & A & - & \\
\hline 3 & (SO)3 & $\begin{array}{l}\text { The use of the country's active-free politics as a mediator for } \\
\text { China and US hegemony in Asia Pacific. }\end{array}$ & V & V & O & V & $\mathrm{O}$ & $\mathrm{O}$ & V & - & & \\
\hline 4 & (ST)1 & $\begin{array}{l}\text { Increase of state budget percentage for the maritime sector } \\
\text { in the development of Navy capability and other } \\
\text { stakeholders }\end{array}$ & $A$ & $A$ & $A$ & A & $A$ & $\mathrm{O}$ & - & & & \\
\hline 5 & (ST)2 & $\begin{array}{l}\text { Negotiations with neighboring countries in trans-state sea } \\
\text { border agreements. }\end{array}$ & $\mathrm{O}$ & V & $A$ & A & $\mathrm{O}$ & - & & & & \\
\hline 6 & $(\mathrm{ST}) 3$ & $\begin{array}{l}\text { Build a strong foundation and infrastructure of information } \\
\text { systems in the maritime territory to cope the cyber threats. }\end{array}$ & $X$ & $A$ & $A$ & A & - & & & & & \\
\hline 7 & (WO)1 & $\begin{array}{l}\text { Establish an integrated task force with fellow stakeholders in } \\
\text { maritime security. }\end{array}$ & 0 & $\mathrm{O}$ & $x$ & - & & & & & & \\
\hline 8 & (WO)2 & $\begin{array}{l}\text { Establish a task force to eradicate corruption and illegal } \\
\text { levies on marine sector. }\end{array}$ & $\mathrm{O}$ & $\mathrm{O}$ & - & & & & & & & \\
\hline 9 & (WT)1 & $\begin{array}{l}\text { Equitable development of maritime infrastructure and } \\
\text { connectivity in coastal and border areas. }\end{array}$ & V & - & & & & & & & & \\
\hline 10 & (WT)2 & $\begin{array}{l}\text { Cooperation with developed countries with technology } \\
\text { transfer for military infrastructure development. }\end{array}$ & - & & & & & & & & & \\
\hline
\end{tabular}

Source: Data Analytic from Author

The second step is to make the reachability matrix and 0 .

(RM) by changing $\mathrm{V}, \mathrm{A}, \mathrm{X}$ and $\mathrm{O}$ with numbers 1

Table 8 Reachability Matrix

\begin{tabular}{c|c|c|c|c|c|c|c|c|c|c|c|c|c}
\hline No & Code & Strategies & $\mathbf{1}$ & $\mathbf{2}$ & $\mathbf{3}$ & $\mathbf{4}$ & $\mathbf{5}$ & $\mathbf{6}$ & $\mathbf{7}$ & $\mathbf{8}$ & $\mathbf{9}$ & $\mathbf{1 0}$ & $\begin{array}{c}\text { Driving } \\
\text { Power }\end{array}$ \\
\hline 1 & $\mathbf{( S O )} \mathbf{1}$ & $\begin{array}{l}\text { Utilization of marine resources to support } \\
\text { renewable energy at sea, and open employment for } \\
\text { the community }\end{array}$ & 1 & 0 & 0 & 0 & 1 & 0 & 1 & 1 & 0 & 0 & 4 \\
\hline 2 & $\mathbf{( S O )} \mathbf{2}$ & $\begin{array}{l}\text { Utilization of the abundant labor force in } \\
\text { recruitment of Navy Personnel }\end{array}$ & 0 & 1 & 0 & 1 & 0 & 0 & 0 & 0 & 0 & 0 & 2 \\
\hline 3 & $\mathbf{( S O ) 3}$ & $\begin{array}{l}\text { The use of the country's active-free politics as a } \\
\text { mediator for China and US hegemony in Asia } \\
\text { Pacific. }\end{array}$ & 0 & 1 & 1 & 1 & 0 & 0 & 1 & 0 & 1 & 1 & 6 \\
\hline 4 & $\mathbf{( S T )} \mathbf{1}$ & $\begin{array}{l}\text { Increase of state budget percentage for the } \\
\text { maritime sector in the development of Navy } \\
\text { capability and other stakeholders }\end{array}$ & 1 & 0 & 0 & 1 & 0 & 0 & 0 & 0 & 0 & 0 & 2 \\
\hline
\end{tabular}




\begin{tabular}{c|c|l|l|l|l|l|l|l|l|l|l|l|l}
\hline 5 & $\mathbf{( S T ) 2}$ & $\begin{array}{l}\text { Negotiations with neighboring countries in trans- } \\
\text { state sea border agreements. }\end{array}$ & 0 & 0 & 0 & 1 & 0 & 0 & 0 & 1 & 0 & 2 \\
\hline 6 & $\mathbf{( S T ) 3}$ & $\begin{array}{l}\text { Build a strong foundation and infrastructure of } \\
\text { information systems in the maritime territory to } \\
\text { cope the cyber threats. }\end{array}$ & 1 & 0 & 1 & 0 & 1 & 0 & 0 & 0 & 1 & 4 \\
\hline 7 & (WO)1 & $\begin{array}{l}\text { Establish an integrated task force with fellow } \\
\text { stakeholders in maritime security. }\end{array}$ & 0 & 1 & 0 & 1 & 1 & 1 & 1 & 1 & 0 & 0 & 6 \\
\hline 8 & (WO)2 & $\begin{array}{l}\text { Establish a task force to eradicate corruption and } \\
\text { illegal levies on marine sector. }\end{array}$ & 0 & 1 & 0 & 1 & 1 & 1 & 1 & 1 & 0 & 0 & 6 \\
\hline 9 & (WT)1 & $\begin{array}{l}\text { Equitable development of maritime infrastructure } \\
\text { and connectivity in coastal and border areas. }\end{array}$ & 1 & 0 & 0 & 1 & 0 & 1 & 0 & 0 & 1 & 1 & 5 \\
\hline 10 & (WT)2 & $\begin{array}{l}\text { Cooperation with developed countries with } \\
\text { technology transfer for military infrastructure } \\
\text { development. }\end{array}$ & 0 & 0 & 0 & 1 & 0 & 1 & 0 & 0 & 0 & 1 & 3 \\
\hline & &
\end{tabular}

Source: Data Analytic from Author

The next step is to make Canonical Matrix to determine the level through iteration.

Table 9 Iteration 1

\begin{tabular}{c|l|l|l|l|r}
\hline No & Code & Reachability & Antecedent & Intersection & Level \\
\hline 1 & (SO)1 & $1,5,7,8$ & $1,4,9$ & 1 & \\
\hline 2 & (SO)2 & 2,4 & $2,3,6,7,8$, & 2 & \\
\hline 3 & (SO)3 & $2,3,4,7,9,10$ & 3 & 3 & \\
\hline 4 & (ST)1 & $\mathbf{1 , 4}$ & $2,3,4,6,7,8,9,10$ & 4 & I \\
\hline 5 & (ST)2 & 5,9 & $1,5,7,8$, & 5 & \\
\hline 6 & (ST)3 & $2,4,6,10$ & $6,7,8,9,10$ & 6,10 & \\
\hline 7 & (WO)1 & $2,4,5,6,7,8$ & $1,3,7,8$ & 7,8 & \\
\hline 8 & (WO)2 & $2,4,5,6,7,8$ & $1,7,8$ & 7,8 & \\
\hline 9 & (WT)1 & $1,4,6,9,10$ & $3,5,9$ & 9 & \\
\hline 10 & (WT)2 & $4,6,10$ & $3,6,9,10$ & 6,10 & \\
\hline
\end{tabular}

Source: Data Analytic from Author

From the Canonical matrix table above, it is and the next Canonical matrix process is not found that the variable (ST)1 is the first iteration included. Strategy (ST)1 at the first Level.

Table 10 Iteration 2.

\begin{tabular}{c|l|l|l|l|l}
\hline No & Code & Reachability & Antecedent & Intersection & Level \\
\hline 1 & (SO)1 & $1,5,7,8$ & 1,9 & 1 & \\
\hline 2 & (SO)2 & 2 & $2,3,6,7,8$, & 2 & II \\
\hline 3 & (SO)3 & $2,3,7,9,10$ & 3 & 3 & \\
\hline 5 & (ST)2 & 5,9 & $1,5,7,8$, & 5 & \\
\hline 6 & (ST)3 & $2,6,10$ & $6,7,8,9,10$ & 6,10 & \\
\hline 7 & (WO)1 & $2,5,6,7,8$ & $1,3,7,8$ & 7,8 & \\
\hline 8 & (WO)2 & $2,5,6,7,8$ & $1,7,8$ & 7,8 & \\
\hline 9 & (WT)1 & $1,6,9,10$ & $3,5,9$ & 9 & \\
\hline 10 & (WT)2 & 6,10 & $3,6,9,10$ & 6,10 & \\
\hline
\end{tabular}

Source: Data Analytic from Author

From the Canonical matrix table above, it is iteration and the next Canonical matrix process is found that the variable (SO)2 is the second not included. (SO)2 at the level II.

Table 11 Iteration 3.

\begin{tabular}{c|l|l|l|l|l}
\hline No & Code & Reachability & Antecedent & Intersection & Level \\
\hline 1 & (SO)1 & $1,5,7,8$ & 1,9 & 1 & \\
\hline 3 & (SO)3 & $3,7,9,10$ & 3 & 3 & \\
\hline 5 & (ST)2 & 5,9 & $1,5,7,8$, & 5 & \\
\hline 6 & (ST)3 & 6,10 & $6,7,8,9,10$ & 6,10 & III \\
\hline 7 & (WO)1 & $5,6,7,8$ & $1,3,7,8$ & 7,8 & \\
\hline 8 & (WO)2 & $5,6,7,8$ & $1,7,8$ & 7,8 & \\
\hline 9 & (WT)1 & $1,6,9,10$ & $3,5,9$ & 9 & \\
\hline 10 & (WT)2 & 6,10 & $3,6,9,10$ & 6,10 & III \\
\hline
\end{tabular}

Source: Data Analytic from Author 
From the Canonical matrix table above, it is found that the variable (ST) 3 and (WT) 2 are the third iteration and the next Canonical matrix process is not included. (ST) 3 and (WT) 2 at the level III.

Table 12 Iteration 4.

\begin{tabular}{c|c|l|l|l|l}
\hline No & Code & Reachability & Antecedent & Intersection & Level \\
\hline 1 & (SO)1 & $1,5,7,8$ & 1,9 & 1 & \\
\hline 3 & (SO)3 & $3,7,9$ & 3 & 3 & \\
\hline 5 & (ST)2 & 5,9 & $1,5,7,8$, & 5 & IV \\
\hline 7 & (WO)1 & $5,7,8$ & $1,3,7,8$ & 7,8 & \\
\hline 8 & (WO)2 & $5,7,8$ & $1,7,8$ & 7,8 & \\
\hline 9 & (WT)1 & 1,9 & $3,5,9$ & 9 & \\
\hline \multicolumn{5}{c}{ Source: Data Analytic from Author }
\end{tabular}

From the Canonical matrix table above, it is found that the variable (ST)2 is the fourth iteration and the next Canonical matrix process is not included. (ST)2 at the level IV.

Table 13 Iteration 5.

\begin{tabular}{c|l|l|l|l|c}
\hline No & Code & Reachability & Antecedent & Intersection & Level \\
\hline 1 & (SO)1 & $1,7,8$ & 1,9 & 1 & \\
\hline 3 & (SO)3 & $3,7,9$ & 3 & 3 & \\
\hline 7 & (WO)1 & 7,8 & $1,3,7,8$ & 7,8 & V \\
\hline 8 & (WO)2 & 7,8 & $1,7,8$ & 7,8 & V \\
\hline 9 & (WT)1 & 1,9 & 3,9 & 9 & \\
\hline
\end{tabular}

Source: Data Analytic from Author

From the Canonical matrix table above, it is found that the variable (WO) 1 and (WO) 2 are the fifth iteration and the next Canonical matrix process is not included. (WO) 1 and (WO) 2 at the level V.

Table 14 Iteration 6.

\begin{tabular}{c|l|l|l|l|c}
\hline No & Code & Reachability & Antecedent & Intersection & Level \\
\hline 1 & (SO) 1 & 1 & 1,9 & 1 & VI \\
\hline 3 & (SO)3 & 3,9 & 3 & 3 & VII \\
\hline 9 & (WT)1 & 1,9 & 3,9 & 9 & VII \\
\hline \multicolumn{4}{r}{ Source: Data Analytic from Author }
\end{tabular}

From the Canonical matrix table above, it is found that the variable (SO) 1 is the sixth iteration. (SO) 1 at the level VI. Variables (SO) 3 and (WT) 1 are the seventh iteration. (SO) 3 and (WT) 1 at the level VII.

The next step, create a model produced by the ISM to solve the problem, in this case the development of posture ability of the Indonesian Navy. From the model, then made implementation strategy based on level (level) that formed. This model can provide the process of the program or activities that will be done first to the final stage.

\subsection{Discussion}

The main purpose of the ISM method is to classify the elements under investigation, according to the driver and dependency. From Reachability matrix, it got the value of Driver Power (DP) and dependence value (D). Based on
DP and D values, elements can be classified into 4 sectors:

1. The autonomous sector is a sector with low DP value and low D value. Elements that fall into this sector are generally unrelated to the system or have little connection.

2. The dependent sector is a sector with a low $\mathrm{DP}$ value and a high D value. Elements that fall within this sector are elements that are not free in the system and are highly dependent on other elements.

3. Linkage sector is sector with high DP value and high $\mathrm{D}$ value.

4. Independent sector is a sector with high DP value and low D value. Elements that fall in this sector can be regarded as a free element. 


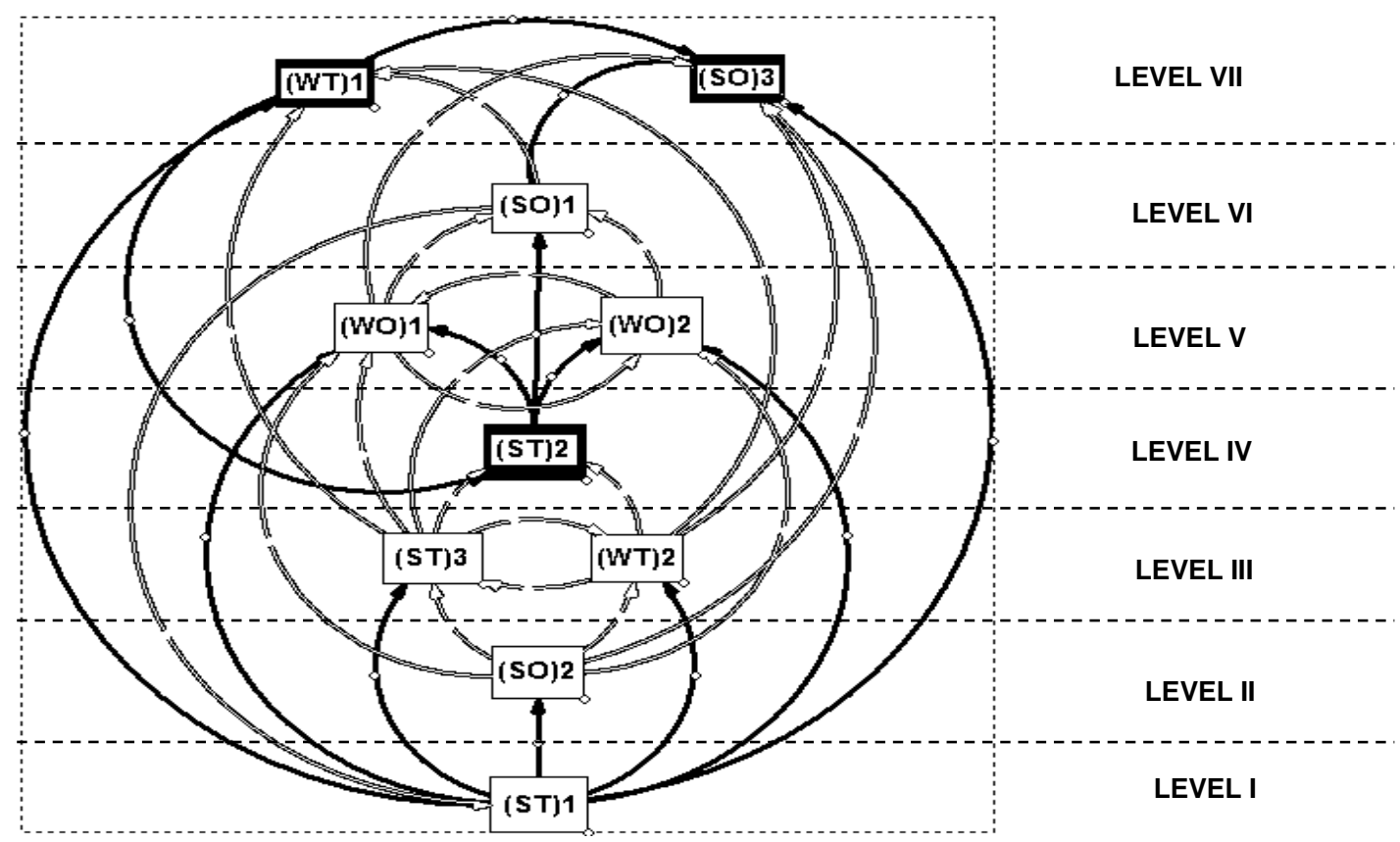

Figure 2 Structural Model of Navy Ability Development Strategy Source: Data Analytic from Author

From the structural model of developing TNI AL posture, the model shows that (ST) 1 is at level I. From Figure 3, it is evident that (ST)1 is a significant driver for the development of the strategy. (SO)2 is at level II; (ST) 3 and (WT)2 are at level III; (ST) 2 is at level IV; (WO)1 and (WO) 2 are at level V; (SO) 1 is at level VI. (WT) 1 and (SO) 3 are at the top of the hierarchy models of structural modeling based on interpretation. This model provides an analysis that the application can assist decision makers in determining the developing strategy of the Indonesia Navy Posture.

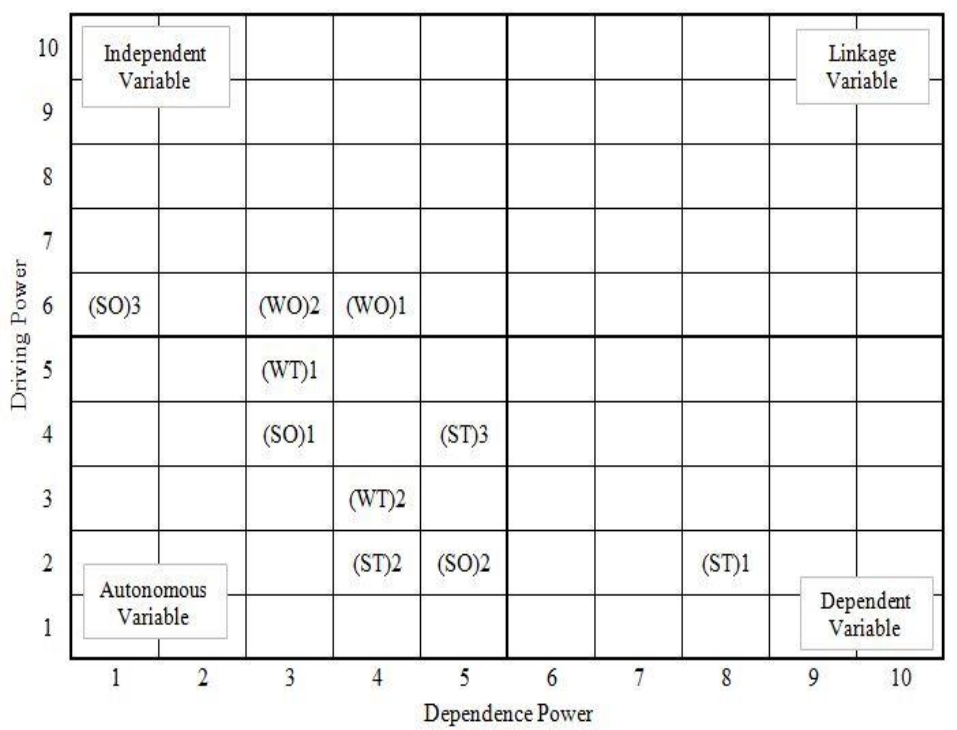

Sector I: Autonomous Driver Sector II: Dependent Driver Sector III: Linkage Driver Sector IV: Independent Driver

Figure3 Driving Power and Dependence Diagram Source: Data Analytic from Author 
From the driver and dependency diagram shown in Figure 4, it is explained that no driver has a strong linkage (sector III). Furthermore, in sector I there are six drivers, namely (WO)1; (SO)1; (ST)3; (WT)2; (ST)2; (SO)2. (ST) 1 is in sector II. In sector IV there are 3 drivers (SO) 3; (WO) 2; (WO) 1 .

According to the results of data analysis with the ISM method, it shows that the strategy (ST)1 is a key element in the strategy of developing the posture of the Navy. This is highly relevant to threats to existing maritime security. The key strategy is an increase of state budget percentage for the maritime sector in the development of Navy ability.

\section{Conclusion}

Based on SWOT analysis, there are several internal factors that become strengths and weaknesses as contained in the table upon. It has eight points for strength analysis factor and seven points for weakness analysis factor. It has seven points for opportunity analysis factor and nine points for threat analysis factor. The total strategy that has been formulated is 10 (ten) sub strategies which determine the development of the Navy posture abilities.

Based on ISM Method, it is evident that (ST)1 is a significant driver for the development of the strategy. (SO)2 is at level II; (ST)3 and (WT)2 are at level III; (ST)2 is at level IV; (WO)1 and (WO) 2 are at level V; (SO)1 is at level VI. (WT)1 and (SO) 3 are at the top of the hierarchy models of structural modeling based on interpretation.

It shows that the strategy (ST)1 is a key element in the developing strategy of the Navy posture. This is highly relevant to threats to existing maritime security. On the other side, the Navy is a non-profit organization. The key strategy is an increase of state budget percentage for the maritime sector in the development of Navy ability.

\section{References}

Attri, R., Dev, N., \& Sharma, V. (2013). Interpretative Structural Modelling (ISM) Approach: an Overview. Research Journal of Management Sciences, 2(2), 3-8.

Balaji, M., Velmurugan, V., Prapa, M., \& Mythily, V. (2016). A Fuzzy Approach for Modeling and Design of Agile Supply Chains using Interpretive Structural Modeling. Jordan Journal of Mechanical and Industrial Engineering, 10(1), 67-74. Retrieved 12 19, 2018, from http://jimie.hu.edu.jo/vol10 1/JJMIE-22-15-01.pdf

Dibokić, M., Nikolić, D., Djordjević, P., Panić, M., \& Živković, Ž. (2017). SWOT - AHP Model for Prioritization of Strategies for Development of Viticulture in Jablanica District - Serbia. Strategic Management, 44-52.
Farrokhi, V., Pokorádi, L., \& Bouini, S. (2018). The Identification of Readiness in Implementating Business Intelligence Projects by Combining Interpretive Structural Modeling with Graph Theory and Matrix Approach. Acta Polytechnica Hungarica, 89-102. Retrieved from https://www.uniobuda.hu/journal/Farrokhi_Pokoradi_Bouini_81.pdf

Firoz, N., \& Rajesh, R. (2012). Relationship among Supplier Selection Criteria using Interpretative Structural Modeling for Manufacturing Organization in Kerala. International Journal of Engineering Science Invention, 3(8), 60-70. Retrieved from http://www.ijesi.org/papers/Vol(3)8/Version2/10382060070.pdf

Gürel, E., \& Tat, M. (2017). SWOT Analysis: A Theoritical Review. The Journal of International Social Research, 10(51), 994-1006. https://doi.org/10.17719/jisr.2017.1832

Hussain, M. (2011). Modelling the Enablers and Alternatives for Sustainable Supply Chain Management. Montreal: Concordia University. Retrieved March 23, 2018, from https://spectrum.library.concordia.ca/7199/1/Hussain_M ASc_S2011.pdf

Jadhav, J. R., Mantha, S. S., \& Rane, S. B. (2015). Analysis of Interaction among the Barriers to JIT Production: Interpretative Structural Modeling Approach. Journal of Industrial Engineering International, 11, 331-352. https://10.1007/s40092-014-0092-4

Lumaksono, H. (2014). Implementation of SWOT-FAHP Method To Determine The Best Strategy on Development of Traditional Shipyard in Sumenep. Academic Research International, 5(5), 56-67. Retrieved March 23, 2018, from http://www.savap.org.pk/journals/ARInt./Vol.5(5)/2014(5 .5-07).pdf

Malik, S. A., Al-Khatani, N. S., \& Naushad, M. (2013). Integrating AHP, SWOT and QSPM in Strategic Planning an Application to College of Bussiness Administration in Saudi Arabia. International Journal of Academic Research, 5(5), 373-37. https://10.7813/2075-4124.2013/5-5/B.58

Marić, V. A., \& Ilić, G. (2012). Strategic Management of Information Systems in the Function of Efficient Business of Companies. Strategic Management, 17(3), 36-46.

https://doi.org/005.21:334.72.021

Ministry of Defence, T. R. (2015). Indonesian Defence White Paper. Jakarta: Ministry of Defence of the Republic of Indonesia.

Njoroge, J. K., Ongeti, W. J., Kinuu, D., \& Kasomi, F. M. (2016). Does External Environment Influence Organizational Performance? The Case of Kenyan State Corporations. Management and Organizational Studies, 3(3), 41-51. https://doi.org/10.5430/mos.v3n3p41

Panackal, N., \& Singh, A. (2015). Using Interpretative Structural Modeling to Determine the Relation between Youth and Sustainable Rural Development. Journal of Management and Research, 4(1), 58-64. https://doi.org/10.17697/ibmrd/2015/v4i1/60352

Paramitha, F., \& Nurcahyo, R. (2018). Industrial Strategy Development of Core Competence in Pekalongan City. Bandung: Proceedings of the International Conference on Industrial Engineering and Operations Management. Retrieved March 23, 2018, from http://ieomsociety.org/ieom2018/papers/459.pdf 
Poerwowidagdo, S. J. (2015). Blue Ocean Strategy in Managing Maritime Security. Jurnal Pertahanan, 1(1), 13-26.

https://doi.org/10.33172/jp.v1i1.51

Putra, I. N., Hakim, A., Pramono, S. H., \& Leksono, A. S. (2017). The Effect of Strategic Environment Change toward Indonesia Maritime Security : Threat and Opportunity. International Journal of Applied Engineering Research, 12(16), 6037-6044. Retrieved March 23, 2018, from https://www.ripublication.com/ijaer17/ijaerv12n16_81.pdf

Roy, S., \& Misra, S. (2016). Interpretative Structural Modeling (ISM) of Tratvel and Tourism Enablres. Specialty Journal of Psychology and Management, 2(2), 32-45. Retrieved March 23, 2018, from http://sciarena.com/storage/article/file/AC633Article.pdf

Solke, N. S., \& Singh, T. (2018). Application of Total Interpretive Structural Modeling for Lean Performance A Case Study. International Journal of Mechanical Engineering and Technology (IJMET), 1086-1095. Retrieved 12 19, 2018, from http://www.iaeme.com/IJMET/issues.asp?JType=IJMET $\&$ VType $=9 \& I$ Type $=1$

Susilo, A., Ahmadi, Suharyo, O., \& Pratisna, P. (2017). Applied of Impressed Current Cathodic Protection

\section{$\triangle$ Correspondence}

\section{April Kukuh Susilo}

Directorate of Postgraduate, Studies Program of ASRO Indonesian Naval College Technology (STTAL)

Krembangan, Surabaya 60187, Indonesia.

Email: akukuhsusilo@sttal.ac.id
Design For Fuel Pipeline Network at Naval Base. Iranian Journal of Materials Science and Engineering, 14(2), 41-52. doi:10.22068/ijmse.14.2.41

Wang, M.-T. (2015). Use of a Combination of AHP and ISM for Making an Innovative Rescue Caring Design in Landslide Area. Mathematical Problems in Engineering(2), 1-13. https://doi.org/10.1155/2015/401736

Yogi, P., Rizal, O., Ahmadi, \& Suharyo, O. S. (2017). Feasibility Analysis of Naval Base Relocation Using SWOT and AHP Method to Support Main Duties Operation. Journal of Defense Management, 7(1), 1-8. https://doi.org/10.4172/2167-0374.1000160

Yuksel, I., \& Dagdeviren, M. (2007). Using the Analytic Network Process (ANP) in a SWOT Analysis - A Case Study for a Textile Firm. Information Sciences, 177(16), 3364-3382. https://doi.org/10.1016/j.ins.2007.01.001

Živković, Ž., Nikolić, D., Djordjević, P., Mihajlović, I., \& Savić, M. (2015). Analytical Network Process in the Framework of SWOT Analysis for Strategic Decision Making (Case Study: Technical Faculty in Bor, University of Belgrade, Serbia). Acta Polytechnica Hungarica, 12(7), 199-216. https://doi.org/10.12700/APH.12.7.2015.7.12 